\title{
Seasonal Variation in Larval Density of Limnoperna fortunei (Bivalvia, Mytilidae) in the Iguaçu and Paraná Rivers, in the Region of Foz do Iguaçu, Paraná, Southern Brazil
}

\author{
Débora Pestana $^{1 *}$, Marcio Roberto Pie ${ }^{1,2}$, Antonio Ostrensky ${ }^{1,3}$, Walter Antonio Boeger ${ }^{1,2}$, \\ Cleverson Andreoli ${ }^{4}$, Francisco Franceschi ${ }^{3}$ and Patrícia Lagos ${ }^{4}$ \\ ${ }^{1}$ Grupo Integrado de Aqüicultura e Estudos Ambientais; ${ }^{2}$ Departamento de Zoologia; ${ }^{3}$ Departamento de Zootecnia; \\ Universidade Federal do Paraná; deborapestana@yahoo.com.br; 81531-990; Curitiba - PR - Brazil \\ ${ }^{4}$ Departamento de Meio Ambiente; Companhia de Saneamento do Paraná; Curitiba - PR - Brazil
}

\begin{abstract}
The larval density of the invasive mussel Limnoperna fortunei (Bivalvia, Mytilidae) was monitored from January 2005 to February 2006 at two points along the Paraná and the Iguaçu Rivers, near Foz do Iguaçu, PR, Brazil. The results indicated two density peaks in the Paraná River: a lower peak between March and June and a higher peak in October. In the Iguaçu River, the values were much lower, yet they also showed a peak between September and October. A reduction in the reproductive activity was observed in both the rivers between July and August. The average larval density at the collection point in the Paraná reached 948.5 larvae/ ${ }^{3}$, with a peak of $2,999.5$ larvae $/ \mathrm{m}^{3}$ in October. The present study represented the first quantification of the larval density of $\underline{\underline{L}}$. fortunei in the lower reaches of the Iguaçu River, downstream of the Iguaçu falls.
\end{abstract}

Key words: Invasive species, golden mussel, biofouling, larval density

\section{INTRODUCTION}

The invasive mollusk Limnoperna fortunei, a native species of the Southeast Asia, was first recorded in South America in 1991 (Pastorino et al., 1993). Since then, this species (commonly known as the golden mussel) has expanded considerably its geographical range, spreading into the largest rivers systems of the Plata basin (de la Plata, Paraná, Uruguay and Paraguay rivers) and causing severe economic problems to the industries, water treatment facilities and hydroelectric power plants of the region (Darrigran et al., 1998; Cataldo and Boltovskoy, 2000), as well as to native environments (Darrigran et al., 1998; Montaldo et al., 1999,
Porta, 2001)..In Brazil, the occurrence of the golden mussel has been recorded in the basins of the Paraguay, Uruguay, Paraná, and Tietê rivers, as well as in the lacustrine environments such as the Lago Guaíba and the Lagoa dos Patos (Mansur et al., 1999, Capitoli and Bemvenuti, 2004, MMA, 2004). Oliveira et al. (2004) reported the presence of this species throughout the extension of the Paraguay river. Also, several authors have described in detail the presence of $L$. fortunei in the Paraná river (Zanella and Marenda, 2002; Takeda et al., 2003; Avelar et al., 2004).

The dispersion of the golden mussel in the Paraná river has raised particular concern for several reasons. With an extension of $2739 \mathrm{~km}$, the Paraná river has the second largest drainage basin oin

*Author for correspondence 
South America $\left(2.6 \times 10^{6} \mathrm{~km}^{2}\right.$, Depetris and Kempe 1993). As a consequence, the ParanáParaguay river transportation system involves the shipment of more than 6 million tones of cargo each year (Silveira, 2005). These activities can provide a means for the dispersal of the golden mussel throughout the Paraná River, particularly in the central Brazil (Oliveira et al. 2000). In addition, the golden mussel has been recorded in all the four hydroelectric power plants on the Paraná River: Itaipu, Ilha Solteira, Jupiá, and Porto Primavera, (Oliveira, 2004).

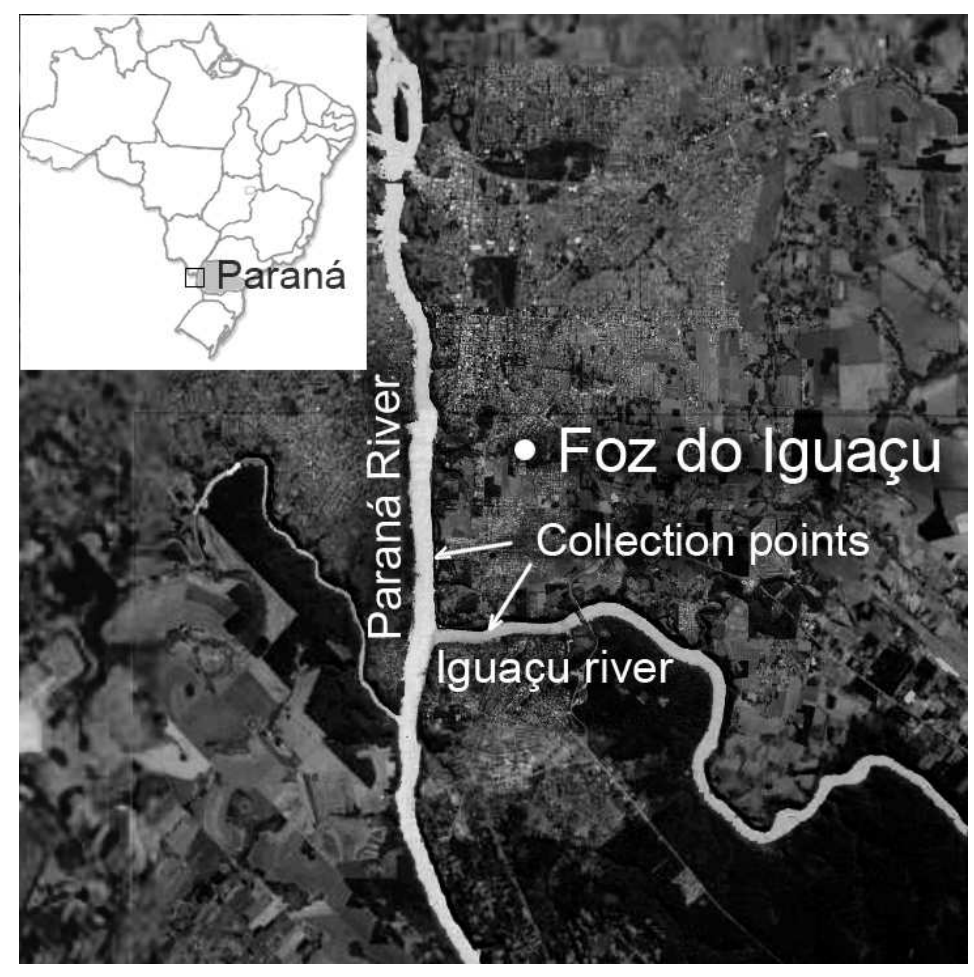

Figure 1. Geographical location of the collection points in the Paraná and Iguaçu rivers.

The colonization of these regions by the golden mussel seems irreversible, and the spread of this species to other river basins in South America seems to be simply a matter of time (Cataldo and Boltovskoy, 2000). However, little is known regarding the occurrence of the golden mussel in the Brazilian portion of the Paraná river. In one of the few reports on this topic, Boltovskoy and Cataldo (2003) analyzed the presence of the larval form in the reservoir of the Itaipu hydroelectric power plant (Foz do Iguaçu, PR) during 2002 and 2003. The knowledge on the distribution of the golden mussel in the Iguaçu river is even more limited. In the only study to date in this respect, Belz et al. (2005) surveyed the main river basins in the State of Paraná, including the Iguaçu river basin, and found that L. fortunei was absent from all the studied basins except for the Paraná River. The goal of the present study was to identify and monitor the temporal variation in the larval density of L. fortunei at two sites (Paraná and Iguaçu rivers, respectively) in the region of $\mathrm{Foz}$ do Iguaçu, 


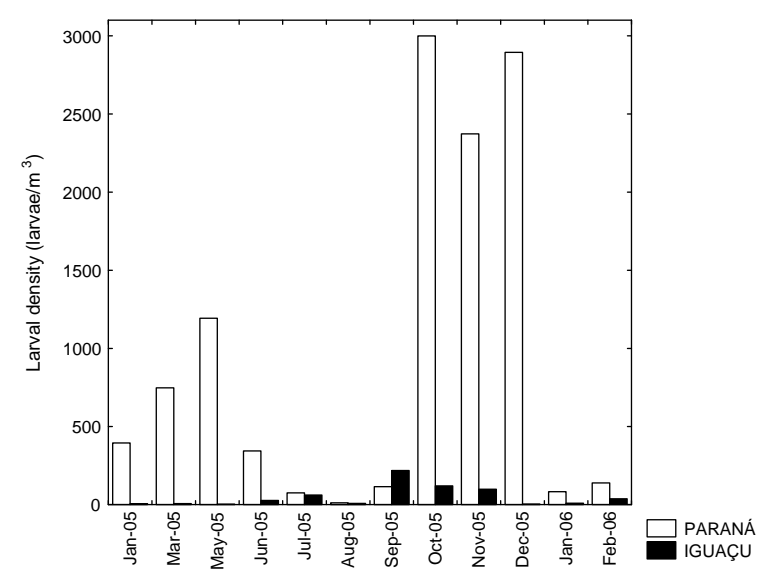

Figure 2 - Larval density of Limnoperna fortunei sampled in the Paraná and Iguaçu rivers

\section{MATERIALS AND METHODS}

The collection sites were located in the municipality of Foz do Iguaçu, State of Paraná, Southern Brazil, upstream of the reservoir of the Itaipu hydroelectric power plant. The site on the Paraná river was located on its left margin $\left(34^{\circ} 34.42^{\prime} \mathrm{S}\right.$ and $\left.54^{\circ} 35.37 .53^{\prime} \mathrm{W}\right)$, whereas the site on the Iguaçu river was located on its right margin $\left(25^{\circ} 35.435^{\prime} \mathrm{S}\right.$ and $\left.54^{\circ} 34.716^{\prime} \mathrm{W}\right)$, approximately $1 \mathrm{~km}$ from the border between Brazil, Paraguay, and Argentina, immediately upstream of the Iguaçu Falls (Fig. 1).The larval density on the studied sites was determined monthly between January 2005 and February,2006. The plankton samples were obtained by filtering $5000 \mathrm{~L}$ of water through a plankton net $(64 \mu \mathrm{m}$-mesh size) using a $0.5 \mathrm{hp}$ water pump. The net was placed in a large bucket $(100 \mathrm{~L})$ such that the water pressure would not damage the collected biological material. The filtered sample was then concentrated and transferred to plastic vials and fixed using $4 \%$ buffered formalin solution. The samples were sorted using a stereoscopic microscope. Each individual was classified as straight-hinged (Dlarvae), veliger, or umbonate larvae (a category that grouped both the umbonate and pediveliger larvae) based on Bostovkoy and Cataldo, 2003. The quantitative analyses were carried out after resampling in a $1 \mathrm{~mL}$ Sedgwick-Rafter chamber.

\section{RESULTS}

There was considerable seasonal variation in the larval density in the studied sites (Fig.2). Two peaks in the larval density could be distinguished in the Paraná river: a higher peak between September and November, and a smaller peak between March and May. The smallest density values were recorded during the colder months, in July and August (Fig. 2). A tendency toward the bimodality was also observed in the Iguaçu river, although the pattern was not as clear as in the case of the Paraná river. The larval density in the Paraná river was usually higher than in the Iguaçu river, with one exception (September 2005). In general, the larval densities in the Iguaçu river were fairly low, with values between 3 and 218 larvae $/ \mathrm{m}^{3}$.

When different larval stages were analyzed separately, the peaks in larval density in the Parana river coincided with a high abundance of veliger larvae. On the other hand, a peak in the umbonate larvae was recorded in December, a time when the veliger larvae were virtually absent (Fig. 3a). In the Iguaçu River, the stages that contributed the most to the abundance peaks of July, September, and November were the umbonate and D-larvae, whereas the peak in October was mostly composed of veligers (Fig. 3b). 


\section{DISCUSSION}

The larval density values recorded in the present study for the Paraná river coincided with those in the reservoir of the Itaipu power plant, upstream of the sites sampled in the present study (Pestana et al., unpublished data), including the peaks in abundance in May-June and October and the decrease in the larval density in the Paraná river during the coldest months of the year. These data indicated the existence of a reduction in the reproduction of $L$. fortune $i$ which, according to the data in the present study, occurred between the months of July and August. Cataldo and Boltovskoy (2000) carried out a survey of the larval stages of the golden mussel in the region of the lower Paraná River and de la Plata river estuary (Argentina). Between September 1997 and January 1999, they report larval densities of up to 33,706 larvae $/ \mathrm{m}^{3}$ (February 1998). Another survey conducted by Boltovskoy and Cataldo (2003) indicated that most of the larval density values in the reservoir were under $500 \mathrm{larvae} / \mathrm{m}^{3}$ over the course of their study (March 2002 to April 2003), and only rarely exceeded 1,500 larvae $/ \mathrm{m}^{3}$. This difference in larval density has been attributed to the relatively recent introduction of this species into the reservoir, when compared to the nearly 10 years of the presence of the golden mussel in the region of the lower Paraná River and the de la
Plata river estuary at the time of their study (Boltovskoy and Cataldo 2003).

In the present study, the average annual density of larvae of $L$. fortunei in the plankton of the Paraná River was 948.5 larvae $/ \mathrm{m}^{3}$, with a peak of $2,999.5$ larvae $/ \mathrm{m}^{3}$ in October. These values were lower than those at the Itaipu reservoir, which averaged $2,755 \mathrm{larvae} / \mathrm{m}^{3}$, with a peak of $17,369 \mathrm{larvae} / \mathrm{m}^{3}$, also in October of the same year. This difference in density may be associated to the differences in the dynamics of these two environments, in which the lentic condition would expedite the establishment of the golden mussel.

The present study reported for the first time the density of larval stages of $L$. fortunei in the Iguaçu river. Although these levels were low (annual average of $50.1 \mathrm{larvae} / \mathrm{m}^{3}$ ), the identification of larvae in the Iguaçu river underscores the risk of invasion of this important river basin in the State of Paraná.Although the Iguaçu falls represented an important natural barrier to the spread of the golden mussel, the site sampled in the present study was used by a local mining company as a source of sand, which was removed from the river bed. This could be a potential means for the dispersal of the golden mussel to the regions upstream of the falls. The competent authorities should implement policies to prevent this means of dispersal of the golden mussel. 


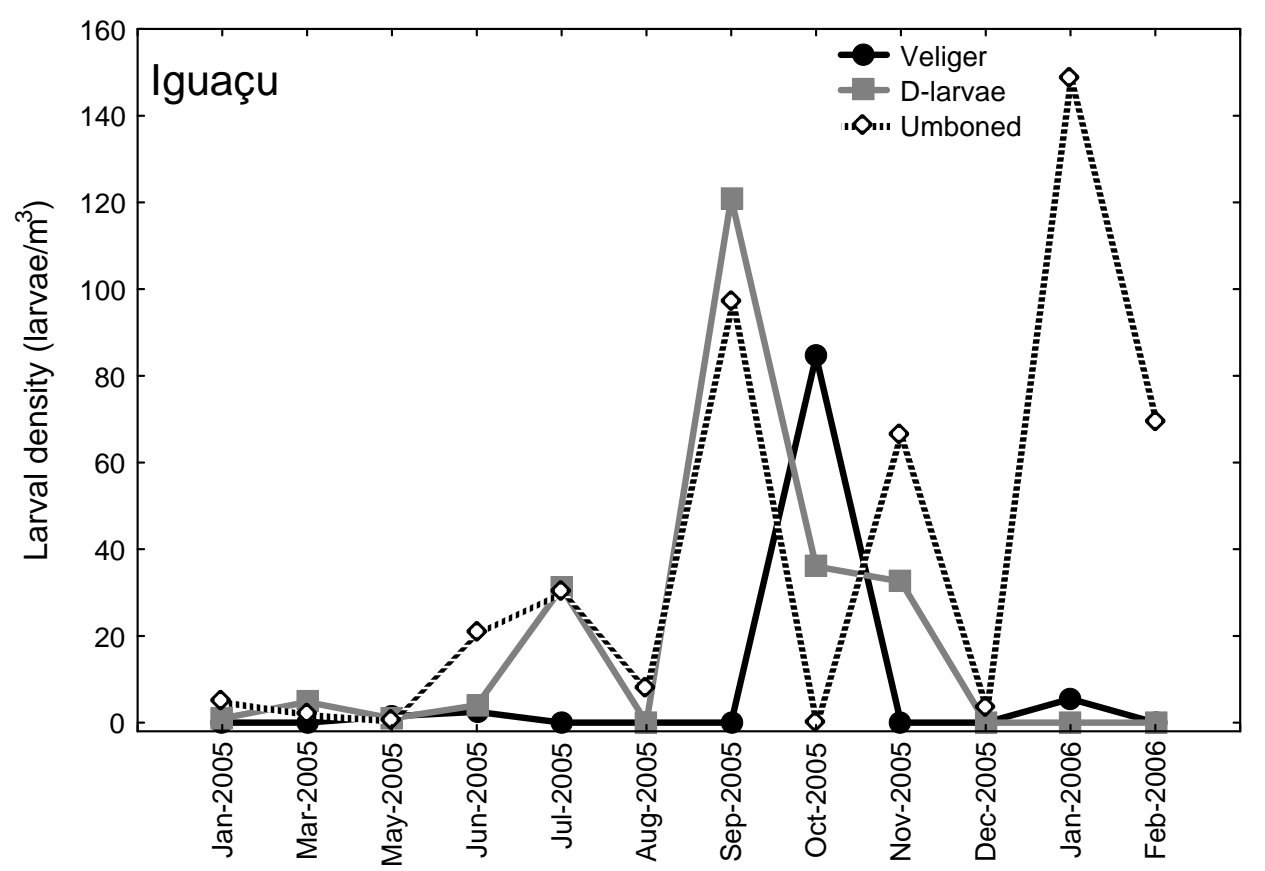

Month/year

A

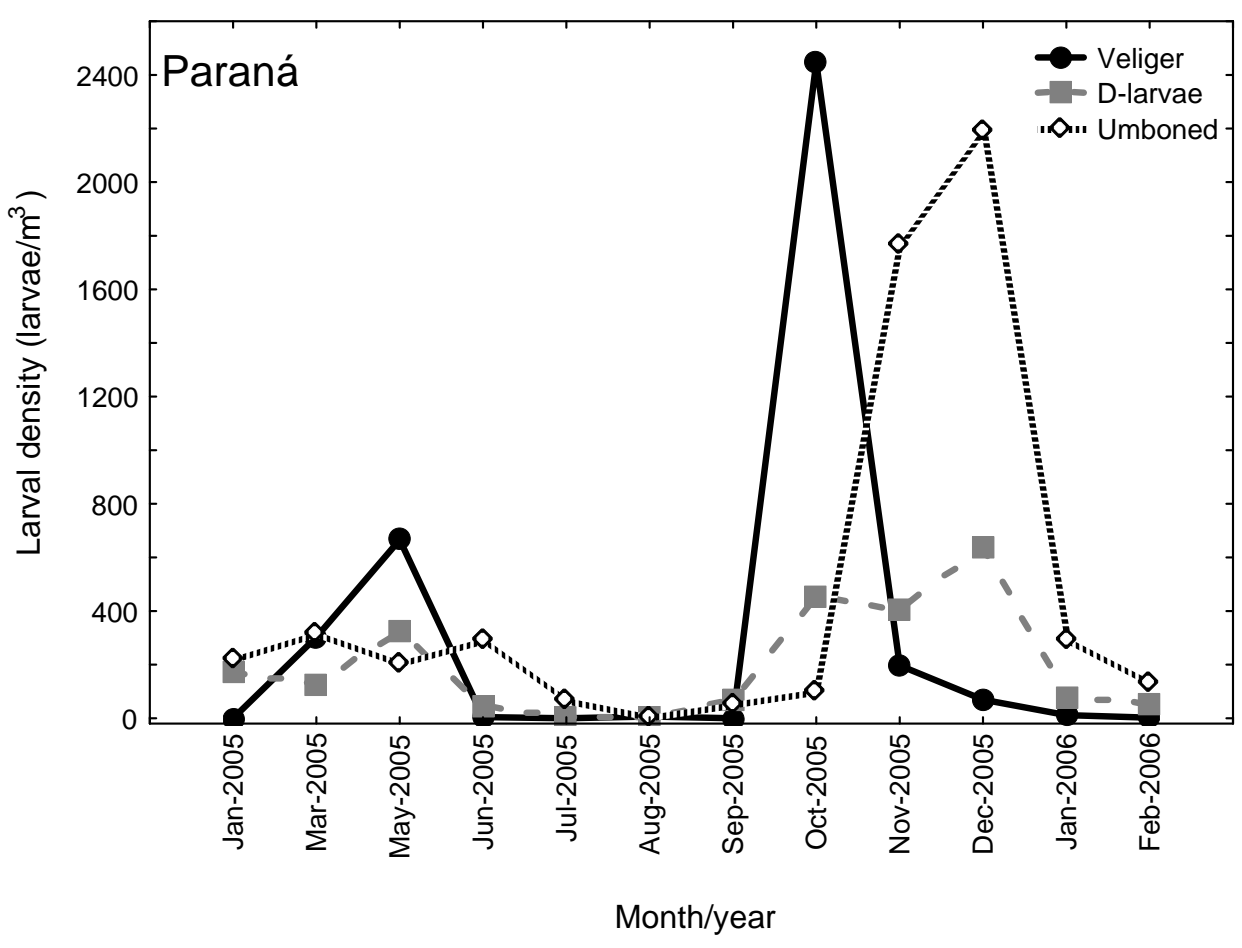

B

Figure 3 - Relative abundance of different larval stages of Limnoperna fortunei in the Iguaçu (3a) and Parana (3b) rivers

\section{ACKNOWLEDGEMENTS}

We thank the staff of the Vila C Water Treatment

Station and Karina Miréia for assistance during the field collection and Robson Ventura de Souza for editing Fig. 1. 


\section{RESUMO}

A densidade larval do molusco invasor Limnoperna fortunei (Bivalvia, Mytilidae) foi monitorada entre janeiro de 2005 e fevereiro de 2006 em dois pontos dos rios Paraná e Iguaçu, na região de Foz do Iguaçu, PR. Os resultados registraram dois picos de densidade no rio Paraná: entre março e junho e um maior em outubro. No rio Iguaçu, os valores foram muito inferiores, mas também com um pico entre setembro-outubro. Em ambos os rios foi verificada uma pausa reprodutiva entre os meses de julho-agosto. A densidade média de larvas de $L$. fortunei no ponto amostrado no rio Paraná chegou a 948.5 larvas $/ \mathrm{m}^{3}$, com pico de 2.999,5 larvas $/ \mathrm{m}^{3}$ em outubro. O presente estudo representa a primeira quantificação da densidade larval de L. fortunei no rio Iguaçu, a jusante das Cataratas do Iguaçu.

\section{REFERENCES}

Avelar, W. E. P.; Martim, S. L. and Vianna, M. P. A. (2004), New occurrence of Limnoperna fortunei (Dunker 1856) (Bivalvia, Mytilidae) in the State of São Paulo. Brazil. Braz. J. Biol. 64,739-742.

Belz, C.E.; Boeger, W.A.P.; Alberti, S.M.; Patella, L. and Vianna, R.T. (2005), Prospecção do molusco invasor Limnoperna fortunei (Dunker, 1857) em reservatórios e sistemas de usinas hidrelétricas da Companhia Paranaense de Energia - Copel. Acta Biologica Leopondensia 27, 123-126.

Boltovskoy, D. and Cataldo, D. H. (2003), Estudios de evaluación, monitoreo y análisis de medidas de control de incrustaciones de moluscos bivalvos (Limnoperna fortunei) en las instalaciones de la Central Hidroeléctrica Itaipu. Relatório Técnico.

Capítoli, R.R. and Bemvenuti, C.E. (2004), Distribuição do mexilhão dourado Limnoperna fortunei (Dunker 1857) na área estuarina da lagoa dos Patos e canal São Gonçalo. VI SIMPÓSIO DE ECOSSISTEMAS BRASILEIROS, Anais. 07 a 11/09/2004. São José dos Campos (SP). ACIESP, São Paulo.

Cataldo, D.H and Boltovskoy, D. (2000), Yearly reproductive activity of Limnoperna fortunei (Bivalvia) as inferred from the occurrence of its larvae in the plankton of the lower Paraná river and the Rio da Prata estuary (Argentina). Aquatic Ecology 34, 307-317.

Darrigran,G., Martin,S.M., Gullo,B., and Armendariz, L. (1998), Macroinvertebrates associated with Limnoperna fortunei (Dunker, 1857) (Bivalvia, Mytilidae) in Rio de la Plata, Argentina. Hydrobiologia 367, 223-230.
Depetris, P.J. and Kempe, S. (1993), Carbon dynamics and sources in the Parana River. Limnology and Oceanography 38, 382-395.

Mansur, M. C. D.; Richinitti, L. M. Z.; Santos, C. P. (1999), Limnoperna fortunei (Dunker, 1857), molusco bivalve invasor, na bacia do Guaíba, Rio Grande do Sul, Brasil. Biociências 7: 147-150.

Montaldo, L.; Oliveros, O. B.; Ezcurra de Drago, I.; Demonte, L. D. (1999), Peces del rio Parana Medio predadores de una especie invasora: Limnoperna fortunei (Bivalvia, Mytilidae). Revista de la Facultad de Bioquimica y Ciencias Biologicas de la Universidad Nacional del Litoral 3, 85-101.

Ministério do Meio Ambiente / Secretaria de Qualidade Ambiental nos Assentamentos Humanos. (2004), Relatório final da Força-Tarefa Nacional para Controle do Mexilhão Dourado. Brasília. (11-12).

Oliveira, M. D.; Takeda, A. M.; Barbosa, D. S.; Calheiros, D. F. (2000), Ocorrência da espécie exótica Mexilhão Dourado (Bivalvia, Mytilidae) no rio Paraguai, Pantanal, Brasil. In: SIMPÓSIO SOBRE RECURSOS NATURAIS E SÓCIOECONÔMICOS DO PANTANAL, 3, Corumbá. Resumos. Corumbá: Embrapa Pantanal.

Oliveira, M.D.; Pellegrin, L.A.; Barreto, R.R. and Xavier, I.G. (2004), Área de ocorrência do mexilhão dourado (Limnoperna fortunei) na Bacia do Alto Paraguai entre os anos de 1998 e 2004. Embrapa Documentos 64. 19 p.

Pastorino, G., G. Darrigran, S.M. Martin, and L. Lunaschi. (1993), Limnoperna fortunei (Dunker, 1857) (Mytilidae), nuevo bivalvo invasor en aguas del Rio da Prata. Neotropica 39, 34-36.

Porta, A. (2001), Biomarkers of contamination in coastal aquatic organisms of Rio de la Plata (Argentina). Acta Bioquimica Clinica Latinoamericana, 35, 261-271.

Silveira, J. $\quad$ P. http://www.amcham.com.br/advocacy/informativos/a dvocacy2001-12 10f_arquivo (acesso em 25/01/2006).2005

Takeda, A.M.; Fujita, D.S.; Fontes Jr, H.M. (2003), Bivalves invasores do Rio Paraná. In: Encontro Brasileiro de Malacologia, 18., Rio de Janeiro. Resumos. Rio de Janeiro. 247p.

Zanella, O. and Marenda, L.D. (2002), Ocorrência de Limnoperna fortunei na Central Hidrelética de Itaipu. In: CONGRESSO LATINOAMERICANO DE MALACOLOGIA, 5., São Paulo. Resumos. São Paulo: Instituto Butantã/ Instituto de Biociências USP. 